\title{
Metalepsa auctorială în proza Doinei Ruști
}

Drd. COSTIANU (CHIFU) Georgeta Pompilia

Universitatea „Dunărea de Jos” din Galați

\begin{abstract}
What sets the novel "The ghost in the mill", by Doina Rusti apart is its original narrative style which captures the reader's attention through the reccurence of the metaliterary elements and also through the fact that it relies on a particular ambiguity of the character and of the person, on the character's hybrid nature as well as on the person's depersonalization, on alternating narative levels. Metalepsis is one of the techniques used by Doina Rusti in her novel with the view to shifting between two worlds, the real world and the unreal, metaliterary world, the three diegetic universes in her art. This narrative technique, defined by Gérard Genette as "a fictional transgression of the representation" creates a connection between the novelist and her works of art, through direct transfer from the author's world to a mimetic world.

Doina Rusti's novel makes use of the metalepsis, which entails the effect of mirroring the author and the text, through transgression from the literary work to the author and conversely the other way back. There is evidence in Doina Rusti's novel "The ghost in the mill" of a fictionalized author through its double fictional version.
\end{abstract}

Keywords: Metalepsis, Gérard Genette, Postmodern Literature, Metaliterary World, Narrative Fiction, Fictional Transgression, Doina Ruști.

Relația biografie-operă-realitate reprezintă o problemă controversată, dezbătută de-a lungul timpului de diferite grupări de critică literară. Nu se poate afirma cu exactitate în ce măsură biografia autorului poate influența creația acestuia, dar un lucru este cert și anume că viața autorului, cu toate problemele ei, își lasă amprenta asupra cărții. Și mă refer, aici, în primul rând, la acele aspecte deosebite ale „eului profund" care pot fi reperate în creația autorului.

A-1 elimina pe autor, "a-1 trimite la plimbare”, este o mare eroare ce se poate face în receptarea unei creații, căci, sub o formă sau alta, el revine în text, de aceea, mă aliez, în această privință, cu opinia lui Eugen Simion, care consideră că: „între omul care scrie și omul care trăiește nu-i chiar o prăpastie de netrecut, că strălucirea operei nu ne vindecă de dorința de a ști ceva despre autorul care a scris-o." [1]

Biografia creatorului este considerată a fi un depozit specific de experiență umană acumulată pe parcursul unei vieți, ca o zonă în care sunt 
proiectate toate dorințele, toate nevoile, traumele care au putut marca conștiința unui artist. Biografia artistului poate fi urmărită, cu mare atenție, de cititorul avizat devenit un adevărat „seismograf”, extrem de sensibil, care înregistrează reacțiile specifice determinate de evenimentele traversate de un scriitor sau de un alt tip de creator. De aceea, criticii, de formație diferită, caută în acest ,tezaur inestimabil" reprezentat de viața artistului, acei indici istorici, psihologici sau sociali pe care-i consideră prezenți, la modul conștient sau inconștient, în opera literară.

Putem considera că opera își revendică autorul așa cum este el, de aceea, vom putea mereu regăsi, în paginile cărții, comoara ascunsă a „,eului profund”, a celui care a conceput opera.

Creația reprezintă o provocare atât prin sensurile ascunse ale sale, pe care lectorul este invitat să le descopere și să le descifreze, cât și prin omul pe care îl învăluie în materialul vaporos al ficțiunii. Citându-1 iarăși pe Eugen Simion, putem spune că opera literară „provoacă în noi...curiozitatea de a cunoaște câte ceva despre destinul care se află în spatele ei". [2]

Căutarea originii textului în viața scriitorului sau a universului său reprezintă o provocare pentru cititor. Această analiză se poate realiza pornind de la ideea că autorul, ca individ, se deconstruiește estetic în universul ficțional. „Sunt oprere de frontieră, pe jumătate romanești, pe jumătate de incursiune referențială, al căror imaginar (scenarii, imagini, teme) acoperă, printr-o punere în scenă abil-naratologică, pe de o parte eul artistului și datele lumii, iar, pe de altă parte, plăcerea jocului textual, care mânuiește lumi posibile, un real-ficțional alimentat de posibilitățile și resursele metalepsei narative, permanentă strategie de subversiune a iluziei ficționale." [3]

O astfel de operă este și romanul „Fantoma din moară” de Doina Ruști, în care autoarea dezvăluie, prin intermediul personajului-narator, tot ceea ce are legătură cu propria realitate, cu ceea ce a trăit, a văzut și a visat. Personajulnarator se naște din aspirațiile, temerile, tristețile, frustrările, întrebările și visurile autoarei sale.

Tocmai de aceea, Doina Ruști utilizează ca procedeu principal metalepsa, în prima parte a romanului său, „Fantoma din moară”, roman remarcabil prin originalitatea de stil. Prozatoarea realizează, în acest roman, o amplă metalepsă narativă care reușește să atragă lectorul în țesătura vaporoasă a textului literar. Această însușire se remarcă, încă din incipitul ex abrupto al romanului, când personajul-narator, care joacă rolul unui adevărat alter-ego al scriitoarei, constată că viața sa reprezintă subiectul unui roman scris de Florian Pavel: 
„O lumină m-a lovit drept în creier și-am rămas lemn, cu ochii legați de geamul vitrinei. Pe coperta bleumarin era numele meu, pe care-l vedeam pentru prima oară pus la vedere. Putea să fie o coincidență. Am citit din nou titlul de pe copertă și-am intrat în librărie. Tejgheaua era plină de cărți, dar eu nu mi-am văzut decât numele. Am deschis cartea și am avut impresia că toată lumea se uită la mine. Mă simțeam ca și când în căpățâna mea s-ar fi deschis ușa unui cuptor încins. In cartea asta era vorba despre mine. Mi-am dat seama chiar de la prima pagină, iar acum, după ce am citit romanul, știu precis”. [„,Fantoma din moară"”pag. 5].

Așa cum Gérard Genette teoretizează relația explicativă, tematică sau enunțiativă pe care o instituie narațiunea metadiegetică cu narațiunea de gradul întâi, Doina Ruști pune accentul, prin romanul său, pe granița categorică, deși alunecoasă, între cele două lumi.

Doina Ruști recurge la metalepsă, în romanul său, deoarece acesta este unul dintre procedeele prin care se realizează glisarea dintr-un plan în altul, real, ireal, metaliterar, cele trei nivele diegetice din romanul „Fantoma din moară". Procedeu naratologic, definit de Gérard Genette ca „transgresare, figurală sau ficțională, a pragului reprezentării" [4], metalepsa pune mereu în relaţie autorul şi opera sa, printr-un transfer din planul creatorului în planul reprezentării mimetice. Prin metalepsă, romanul „Fantoma din moară” reușește să creeze efectul de oglindire a autorului în text, printr-un transfer dinspre operă spre autoare şi invers. Asistăm, astfel, la o ficţionalizare a autorului prin dublul său fictiv. Personaj de roman, naratoarea, cea care vede în vitrina unei librării o carte intitulată „Viaţa secretă a Adelei Nicolescu”, se grăbește s-o cumpere şi are surpriza să-şi găsească acolo propria poveste de viață, prezentată în cele mai intime detalii. Adela Nicolescu, este uluită de întâmplarea prin care trece, de aceea, ea va face câteva investigaţii descoperind că romanul reproduce, de fapt, textul unui blog anonim. Protagonista începe să comenteze la rându-i textul şi să1 completeze cu detalii şi întâmplări colaterale. Cele două texte se suprapun, astfel încât, lectorul constată că autobiografia Adelei respectă misteriosul text al romanului la persoana a treia, istorisind povestea familiei ei. Există, însă, detalii, mici inadvertențe sau inexactități, care, în partea a doua a romanului, vor duce treptat spre „adevăratul autor” al acestui text. Se poate vorbi despre o povestire la persoana a II-a, peste care se suprapune confesiunea Adelei. Cu toate că povestesc aceleași lucruri, cele două texte se completează, prin schimbarea perspectivei epice. Adela are propriile amintiri, care corectează textul romanului semnat de Florian Pavel. Intr-un astfel de episod, Adela narează o întâlnire 
neașteptată cu Sile Nicolescu, bunicul ei, iar confesiunea ei se completează cu textul lui Pavel:

„Într-o dimineață a apărut bunicul la școală. Am ieșit în pauză și l-am văzut pe coridor. Stătea lângă o fereastră, cu pălăria maro ușor ridicată de pe frunte, descheiat la pardesiu și cu bastonul albicios atârnat pe braț. Era încurcat, ca și când s-ar fi întâmplat o catastrofă:

"Sile Nicolescu se uita pentru prima oară la nepoata lui ca la o ființă străină, nu doar pentru că, în uniforma ei de liceu, părea înfășurată într-un sac, ci pentru că nu știa de fapt prea clar ce trebuia să-i spună.

- Uite, a început el, nu știu cum să-ți spun...

Ea stătea cu-o mână în buzunarul sarafanului bleumarin și cu cealaltă rezemată de pervazul ferestrei:

- Spune-mi repede, că n-am decât cinci minute pauză". [Fantoma din moară- pag. 102].

Cele două texte se completează, creând iluzia obiectivizării. Amintirea, readusă într-un prezent al reconstituirii, își întărește poziția prin textul de tip realist, în care Adela se transformă din naratoare în personaj văzut de un ochi imparțial. Acest joc, plasat în spațiul unei glisări veridice, face ca fiecare episod să se amplifice. Evenimentul epic, rupt de context, plasat înaintea faptelor care 1au declanșat, aduce numeroase detalii care nu au atât rolul de a corecta o eroare din textul lui Pavel, ci de a consolida acțiunea prin detalii, cauze și personaje. $\mathrm{Nu}$ contează faptul că o culoare de rochie nu corespunde cu amintirile Adelei, ci evenimentele care o fixează într-un topos, pe cât de subiectiv, pe atât de credibil.

Copilăria Adelei se află, încă de la început, sub semnul unor fantasme legate de moara părăsită, locul apariţiei unei siluete masculine și anume, Max. Acesta i se arată, prima dată, micuței Adela, în moară, cu prilejul morţii unchiului ei, apoi, după ce personajul ajunge la vârsta adolescenței, fantoma îşi pierde identitatea, devenind obsesia suprapusă a tuturor bărbaţilor pe care Adela îi întâlneşte.

După maturizarea Adelei, acest filon psiho-fantastic dispare şi se face trecerea definitivă spre planul realist, care ne oferă un fel de monografie subiectivă a comunităţii satului Comoșteni.

Parafrazând o afirmație a Doiniței Milea, putem vorbi despre niște „trepte organizatoare ale subversiunii metaleptice", capabile să interfereze cu limbajul auctorial, analizat în ceea ce el are emblematic, exact ca un „cod al autorului real". Doina Ruști creează mai multe voci epice, iar, aici, ne referim, în principal, la mărturisirile din dosarul cu lacăt, doar anticipate, în prima parte a romanului, prin comentariile unui narator implicat partial (Adela) în povestea comunității. 
Povestirea la persoana întâi, ca și păstrarea unor repere autobiografice, precum geografia auctorială, referirile la perioada de studii sau la familia reală, fac posibilă această legătură transparentă dintre autoarea romanului și naratorulpersonaj. După cum s-a spus, „bioficțiunea”, invenție a propriei ficțiuni despre sine, presupune voci narative „martore” care să marcheze relația dintre punerea în text a unei identități creatoare, ficționalizarea și contestarea frontierelor dintre real și imaginar. Doina Ruști recurge la o galerie impresionată de caractere care pe parcursul romanului reiau, reconfirmă și completează confesiunea personajului narator, astfel încât, „dosarul de existență” al unui personaj se transformă treptat în istoria unei comunități, la rândul ei metamorfozată, construită în planul unei istorii reale, ca mai apoi, să se dilate, să crească insesizabil, în planul ficțiunii pure. Acțiunea este plasată în zilele exploziei de la Cernobâl, utilizând informații recognoscibile, referiri la documente și persoane reale - plasate, însă, într-un context imaginar. De multă vreme proza, mai ales, cea înscrisă în așa-zisul realism magic, amestecă planurile, după unele opinii, acest simptom semnalând o „estetică a degradării canonului mimetic”, dar constituindu-se totodată și într-un act de complicitate cu cititorul, fidelizat prin apelul la o istorie comună. În procesul „de producere și recunoaștere a sensurilor, consumatorul de text, lectorul, este provocat să devină complice, prin atragerea atenției asupra procesului de ficționalizare, fie prin notații metanarative punctuale, fie prin „puneri în abis" dezvoltate”.[5]

În acest sens, Doina Ruști îşi structurează romanele pe două planuri, cel al realului şi cel al imaginarului. Situându-și personajele în cronotopul istoric, satul Comoșteni, dinainte de 1989. Preluând anumite elemente ale realismului (referentul istoric, geografic), le inventează, însă, existenţa, la fel cum inventează propria biografie, combinând elemente realiste cu elemente ale „unei realităţi fictive". Romanul capătă, astfel, conotații autobiografice, dar amănuntele din viața autoarei sunt abil camuflate printre ițele vaporoase ale scriiturii sale. Corelând mărturisirile scriitoarei cu situația familiei Adelei descoperim că cele două povești de viață se aseamănă întrucâtva. Dintr-un interviu al Doinei Ruști, aflăm că în familia ei a existat un bunic care stătuse în lagăr la ruşi. De asemenea, episodul în care cărțile familiei sunt arse în curte are o bază reală, în istoria întunecată a stalinismului românesc. Multe alte evenimente epice devin plauzibile prin tensiunea poveștii, dar, mai ales, prin încadrarea lor în miturile comunismului: tatăl fugit peste graniță, crezut mort ani în şir, sau disparițiile inexplicabile, așa cum este, aici, episodul despre mama adulteră „pierdută” în moară. 
Un loc special îl are portretul lui Max, diseminat de-a lungul romanului, evocând cu subtilitate portretul lui Ceaușescu, nu atât prin descriere, cât prin omniprezența lui, un fel de efigie a lumii comuniste.

Restul personajelor din sat sunt prinse într-un confuz vârtej, ceea ce întărește latura fantastică a romanului.

În „Fantoma din moară”, lectorul poate sesiza o permanentă distanțare de registrul referențial istoric şi o glisare subtilă în planul ficțiunii, printr-o deformare a elementelor reale, ca un fel de halucinaţie prin care se iese din real şi se pătrunde în ireal, apoi se revine la reprezentarea mimetică a realului.

Doina Ruști alternează realul cu irealul, ficțiunea cu o realitate paralelă în care intră şi din care ies personajele, inclusiv naratorul-autor. Realismul mimetic e doar un pretext pentru a fantaza prin recurs la ficțiune. Această idee este întărită, în text, prin utilizarea unuia dintre motivele recurente ale romanului și anume motivul oglinzii, ca obiect care reflectă identitatea personajului-narator, dar şi opera ca modalitate de introducere a autorului în ficţiune. Personajele își schimbă înfățișarea, devenind de-a lungul acțiunii un fel de „clone” ale marelui stăpân, pe cât de discret, pe atât de prezent în mințile și, mai ales, în intimitatea fiecărui personaj. Este vorba despre Max, fantoma din moara părăsită. Totodată, printr-o punere în abis, autorul-narator-actor se reflectă în țesătura fină a discursului narativ. Oglinda este un alter-ego prețios, care nu obligă la depășirea propriei identități, ci dimpotrivă, îndeamnă la contemplarea de sine.

Înainte de a fi un roman al supranaturalului, „Fantoma din moară” e cronica unei comunități distruse în epoca diabolică a unui comunism văzut în latura sa cea mai crudă, a depersonalizării. Cu un instinct de romancier original, Doina Ruşti evită să caracterizeze pozitiv ori negativ oamenii şi faptele lor. Istoria fiecăruia se desfăşoară în limitele impuse de către noul Centru. Dar treptat, toată lumea începe să semene cu marele conducător.

Un roman realist construit prin trucuri clasice şi instanţe narative moderne, în doar câteva sute de pagini: roman în roman, manuscris anonim şi ficțiune ca fantasmă impersonală.

În ciuda intenției realiste, Doina Ruști construieşte o ficţiune antimimetică postmodernă, în care orice iluzie realistă este spulberată prin alunecări din planul real în cel fictiv, prin depăşirea pragului între universul diegetic al poveştii relatate şi universul metadiegetic al autorului care intră în diegeză.

Mai ales structura romanului aduce înnoiri spectaculoase, fiind alcătuit din trei părți, care narează aceeași poveste din perspective și în registre total diferite. Povestea Adelei, spusă la rândul ei din două direcții (cea a lui Pavel si cea a Adelei însăși) capătă sens abia după ce aflăm povestea comunității, bântuită 
de fantoma din moară. În această a doua parte, care este, după cum s-a spus în nenumărate rânduri, și partea cea mai consistentă a cărții, Adela nu este decât un personaj pasager, însă istoria ei capătă confirmarea unei opinii publice. Perspectiva largă, tonul obiectiv și viziunea halucinant-seducătoare aduc pe scenă o poveste cu deschidere clasică. Ultima parte este compusă din povestea a două zile din viața unui învățător, două priviri parcă aruncate pe niște ferestre înguste ale istoriei. Dar din aceste două episoade aflăm de fapt adevărata relație dintre autor și text. De la romanul descoperit în vitrina unei librări, până la manuscrisul lui Sile Nicolescu, povestea parcurge un labirint în care sunt plasați cu artă indecșii metalepsei inițiale. Bătrânul neimportant în prima parte a romanului, care își privește nepoata fără să știe cum să-și înceapă povestea, devine finalmente autorul poveștii și cauza principală a fantomei.

Lumea romanului „Fantoma din moară” este un adevărat spectacol evocat, montat în imagini de o mare autenticitate, care satisface un anumit orizont de așteptare. Autoarea suprapune, în romanul ei, universul cuvintelor și pe cel al imaginilor, creând din motivul fantomei un fel de receptor al obsesiilor, viselor, dorințelor generale, introducând todată elemente imaginare credibile, capabile să-i producă lectorului satisfacția recunoașterii.

\section{Note finale:}

[1] Simion, Eugen - Întoarcerea autorului. Eseuri despre relația creator-operă, Editura Cartea Românească, Bucureşti, 1982, pag.5.

[2] ibidem, pag. 7.

[3] Milea, Doinița, „Coerența ficțiunii-între canonul mimetic și exerciţiile metanarative", în Annales Universitatis Apulensis.Series Philologica, Literatură română și comparată, 2006.

http://www.uab.ro/reviste recunoscute/philologica/philologica 2006/philologica 2006.html

[4] apud, Milea, Doinița, „Coerența ficțiunii-între canonul mimetic și exercițiile metanarative", în Annales Universitatis Apulensis.Series Philologica, Literatură română și comparată, 2006.

[5] ibidem 


\section{Referințe bibliografie:}

Cenac Oana, Discurs ideologic în "Ateneu" 1965, Actele conferinţei internaţionale Lexic comun / Lexic specializat. Democratizarea cunoașterii" sau migrația lexicului specializat spre lexicul comun, ediția a X-a, Universitatea „Dunărea de Jos” din Galați, Facultatea de Litere, Centrul de Cercetare Comunicare interculturală și literatură, 19 - 20 mai 2017, publicată în Analele Universității „Dunărea de Jos” din Galați, Fascicula XXIV Lexic comun / lexic specializat, revistă indexată in bazele de date internaționale EBSCO: https://www.ebscohost.com/titleLists/cms-coverage.pdf, MLA (Modern Language Association, New York, www.mla.org) - MLA International Bibliography \& Directory of Periodicals, CEEOL și Fabula. La recherche en littérature (www.fabula.org), anul X, nr. 2(18) /2017, Editura Casa Cărții de Ştiință, Cluj-Napoca, 2017, ISSN 1844-9476, p. 31-48.

Cenac Oana, General aspects of current political terminology, în Lexic politic - discurs politic, 2014, p.124-130, ISBN:978-606-17-0633-4, WOS: 000378358200007.

Ifrim, Nicoleta, Theoretical Aspects of Identity Discourse in Post-totalitarian Cultures, în Procedia-Social and Behavioral Journal (ISSN: 1877-0428) (ISSN: 1877-0509), vol.63/2012 ELSEVIER, p. 35-40, DOI 10.1016/j.sbspro.2012.10.007, http://www.sciencedirect.com/science/journal/18770428/63/supp/C, WOS:000361477200006.

Ruști, Doina, Fantoma din moară, Editura Polirom, București, 2017.

Călinescu, Matei, Cinci fețe ale modernităţii. Modernism, avangardă, decadență, kitsch, postmodernism. Traducere de Tatiana Pătrulescu şi Radu Țurcanu, postfaţă de Mircea Martin, Editura Univers, Bucureşti, 1995.

Călinescu, Matei, A citi, a reciti. Către o poetică a (re)lecturii. Traducere de Virgil Stanciu, Editura Polirom, Iaşi, 2003.

Genette, Gérard, Figures III, Paris, Seuil, 1972.

Genette, Gérard, Fiction et Diction, Paris, Seuil, 1991.

Marino, Adrian, Biografia ideii de literatură, I-VI, Cluj-Napoca, Dacia, 1990-2000.

Ricardou, Jean, Problèmes du Nouveau Roman, Paris, Seuil, 1967. 